\title{
A new species of Ctenobrycon Eigenmann, 1908 (Characiformes: Characidae) from the río Orinoco basin, Venezuela
}

\author{
RICARDO C. BENINE ${ }^{1}$, GUILHERME A. M. LOPES ${ }^{1} \&$ ERNESTO RON $^{2}$ \\ ${ }^{1}$ Laboratório de Biologia e Genética de Peixes, Departamento de Morfologia, IBB-UNESP Campus de Botucatu, Botucatu, SP, 18600- \\ 000, Brazil.E-mail: rbenine@ibb.unesp.br \\ ${ }^{2}$ Laboratorio de Ictiología. Escuela de Ciencias Aplicadas del Mar. Universidad de Oriente, Núcleo Nueva Esparta, Isla de Margarita, \\ Venezuela
}

\begin{abstract}
Ctenobrycon oliverai, new species, is described from the río Orinoco drainage and its main tributary, río Apure, Venezuela. This species is readily distinguished from its congeners by the high number of series of scales above lateral line and by morphometric differences in body depth, head length, and interorbital distance. Statistical multivariate analysis was also conducted in order to test hypothesized differences among species of Ctenobrycon. A brief discussion on the taxonomy of this genus is provided.
\end{abstract}

Key words: Taxonomy, Neotropical, Freshwater, Ctenobrycon spilurus

\section{Resumo}

Ctenobrycon oliverai, espécie nova, é descrita do río Orinoco e seu tributário principal, río Apure, Venezuela. A nova espécie é prontamente distinguida de seus congêneres pelo maior número de séries de escamas acima da linha lateral e por diferenças morfométricas observadas na altura do corpo, comprimento da cabeça e distância interorbital. Uma análise estatística multivariada foi empregada com o objetivo de se testar as supostas diferenças entre as espécies de Ctenobrycon. Uma breve discussão sobre a taxonomia deste gênero é apresentada.

\section{Introduction}

Ctenobrycon is a genus of small characid fishes widely distributed in the Amazon, Orinoco and Paraguay river basins (Eigenmann, 1927; Lima et al., 2003). Currently with three valid species, C. spilurus (Vallenciennes, 1850), C. hauxwellianus (Cope, 1870), and C. alleni (Eigenmann \& McAtee, 1907) (Lima et al., 2003), Ctenobrycon was originally proposed by Eigenmann (1908: 94) and simply described as a deeper bodied Astyanax diagnosed from all other Tetragonopterinae by the presence of "ctenoid" scales. Subsequently, Eigenmann (1927: 330) provided a more detailed and informative description for this genus which includes species bearing a deep and compressed body (2.0 to 2.5 times in SL); long anal fin (39-47 total rays) with its margin nearly straight and its origin behind or below the origin of the dorsal; mouth very small, the maxillary not reaching the eye; ctenoid scales in the preventral area, cycloid scales in the sides in young, becoming ctenoid in adults; lateral line complete (extremely variable number of pored scales, with all possible counting from 36 to 49); caudal fin naked; maxillary with nine (clearly an error) to two teeth; a series of tricuspid teeth in the premaxillary and an inner series of pentacuspid teeth, whose cusps are arranged in a U-shaped curve.

Although Ctenobrycon is defined by a combination of characters which have been long discussed to have limited phylogenetic information (see Malabarba, 1998:194 and Vari, 1998:111), it is relatively well characterized and easily recognized among small characins (with the exception of Psellogrammus kennedyi Eigenmann, a very similar species and putatively related to Ctenobrycon [see Mirande, 2010], from which it simply differs by 